\title{
Acute cold exposure and the metabolism of blood glucose, lactate and pyruvate, and plasma amino acids in the hind leg of the fed and fasted young ox
}

\author{
BY A. W. BELL, J. W. GARDNER, W. MANSON \\ AND G. E. THOMPSON \\ The Hannah Research Institute, Ayr $\mathrm{KA}{ }_{5} \mathrm{HL}$
}

(Received 28 May I974-Accepted 31 fuly 1974)

\begin{abstract}
I. Young steers were fed either $3-4$ or $20 \mathrm{~h}$ before exposure to a thermoneutral or a moderately cold environment. Measurements were made of total oxygen consumption (total $\dot{V}_{\mathrm{O}_{2}}$ ), respiratory quotient (RQ), blood packed cell volume (PCV), and hind-leg blood flow (leg $Q$ ) and oxygen uptake (leg $\dot{V}_{\mathrm{O}_{2}}$ ). The arteriovenous differences in whole blood glucose, lactate and pyruvate, and individual plasma amino acid and urea concentrations across the leg were also measured. Net exchange and fractional uptake of these metabolites by the leg were calculated from these results.

2. Cold exposure doubled total $\dot{V}_{\mathrm{O}_{2}}$, significantly decreased RQ and significantly increased PCV. Leg $Q$ and leg $\dot{V}_{\mathrm{O}_{2}}$ increased 3 - to 5 -fold and 4- to $\mathrm{r}_{3}$-fold respectively in both feeding groups. Arterial blood glucose increased slightly but significantly in both $20 \mathrm{~h}$ - and $3 \mathrm{~h}$-fed steers. There was a substantial increase in mean net leg uptake of glucose in both feeding groups. This was much greater in the $20 \mathrm{~h}$-fed group because of the significant increase in fractional uptake occurring only in this group. Cold did not significantly affect arterial blood lactate or pyruvate levels, but the net leg output of lactate found in both feeding groups in thermoneutrality was increased in the $20 \mathrm{~h}$-fed steers, and reversed to a net uptake in the $3 \mathrm{~h}$ fed animals. Cold caused a small but significant decrease in the total plasma amino acid level in the $20 \mathrm{~h}$-fed but not in the $3 \mathrm{~h}$-fed group; individual amino acid levels or leg uptakes were not affected.

3. Feeding before the experiment caused a significant increase in RQ. Leg $\dot{Q}$, leg uptake of glucose and leg output of lactate increased after feeding in the thermoneutral environment only. Arterial pyruvate increased significantly, but net leg output was not significantly affected by feeding. Arterial plasma concentration of several individual, but not of total amino acids, increased significantly in both environments, and the net output of many individual amino acids in the $20 \mathrm{~h}$-fed steers was decreased or reversed to a net uptake in the $3 \mathrm{~h}$-fed group in thermoneutrality only.

4. The results suggest that blood glucose could be a significant fuel for oxidation in shivering skeletal muscle in young steers, and that output of amino acids from skeletal muscle could not contribute significantly to this increased glucose supply by hepatic gluconeogenesis.
\end{abstract}

Work in this laboratory on the metabolism of the hind leg of the cold-exposed steer (Bell, Thompson \& Findlay, 1974) has indicated that the hind-leg preparation might prove useful in the study of energy substrate utilization by shivering skeletal muscle in the conscious intact animal. This has been borne out by recent reports of increased utilization of plasma-borne volatile fatty acids (Bell, Gardner \& Thompson, 1974) and free fatty acids (Bell \& Thompson, 1974) by the leg during cold exposure; the relative importance of these factors increases depending on the time after feeding. However, even taking into consideration the empirical nature of such estimations, it can be calculated that the substrates so far studied account for no more than $50 \%$ of the energy requirements of the shivering leg.

Although glucose makes only a minor contribution to oxidative metabolism in resting ruminants (Lindsay, 1970), recent work suggests that this is substantially 
increased during acute cold exposure of sheep (McKay, Young \& Milligan, 1974). The uptake of glucose by human skeletal muscle has been shown to increase during exercise (Wahren, Felig, Ahlborg \& Jorfeldt, 1971), but there is no direct evidence for increased blood glucose utilization by shivering muscle in conscious animals of any species. The present work was therefore undertaken to measure the potential contribution of blood glucose and related metabolites to leg metabolism in young steers acutely exposed to cold. The net exchange across the leg of plasma amino acids was also measured, in view of the accelerated rates of skeletal muscle release and splanchnic uptake of alanine in exercising men (Felig \& Wahren, 197x), the dependence of ruminants on gluconeogenesis for much of their glucose supply (Bergman, 1973) and the importance of alanine and other amino acids as glucose precursors in sheep (Reilly \& Ford, r971; Wolff \& Bergman, 1972) and cattle (Black, Egan, Anand \& Chapman, I968).

\section{EXPERIMENTAL}

\section{Animals and diets}

Six Ayrshire steers aged 7-8 months and weighing $108-163 \mathrm{~kg}$ were used. They were housed in an insulated byre in which ambient temperatures ranged from 3 to $18^{\circ}$ and were individually fed with $\mathrm{I} \cdot 5^{-2} \mathrm{~kg}$ of a mixture of chopped straw, rolled barley, cattle pellets and molasses twice daily.

\section{Animal preparation}

Each steer had its right common carotid artery placed in a loop of skin at least I month before experiments began. Permanent indwelling cannulas were placed in the external iliac artery and vein of one hind leg, with the animal under general anaesthesia, at least $5 \mathrm{~d}$ before experiment began (Bell, Thompson \& Findlay, 1974). During the post-operative recovery period the animals were acclimatized to experimental procedures and surroundings, and were clipped over the hind-quarters to increase the rate of cooling during cold exposure.

\section{Experimental design and procedure}

The experiments were designed and carried out in similar fashion to those in a previous study of energy substrate utilization in the young steer (Bell, Gardner \& Thompson, 1974). In each experiment an animal was exposed to either a thermoneutral or a moderately cold environment and was fed either $3^{-4}$ or $20 \mathrm{~h}$ before the experiment started. Water was freely available to all animals until about $2.5 \mathrm{~h}$ before an experiment. 'The four possible combinations of environmental and feeding treatments were replicated three times and each animal was randomly allocated to two experiments. No animal underwent the same treatment combination twice.

The exteriorized carotid artery was cannulated on the morning of experiment. The animal was then placed in a climatic room in which the ambient dry-bulb temperature was maintained at $13-16^{\circ}$ with still air (thermoneutral) or at $0-2^{\circ}$ with a wind of $2 \mathrm{~m} / \mathrm{s}$ blowing over the clipped hind-quarters (moderately cold). During cold exposure the hind-quarters were sometimes lightly wetted to maintain an adequate rate of 
cooling. Measurement of whole-animal oxygen consumption (total $\dot{V}_{\mathbf{O}_{2}}$ ) began immediately and continued throughout the experiment. Other measurements did not begin until total $\dot{V}_{\mathrm{O}_{2}}$ was steady and, during cold exposure, at a level about twice that of the resting $20 \mathrm{~h}$-fed steer. This took I-I.5 h. Duplicate series of experimental measurements were then made, each lasting $15^{-20} \mathrm{~min}$, with about $\mathrm{I}$ h separating the start of each series. During each series paired arterial and venous blood samples for analysis of metabolite and dye concentrations (see below) were taken by syringe over a $5 \mathrm{~min}$ period.

\section{Measurements}

Total $\dot{V}_{\mathrm{O}_{2}}$ and respiratory quotient (RQ) were measured with an open-circuit apparatus modified from that of McLean \& Calvert (1972). Hind-leg blood flow (leg $\dot{Q}$ ) was measured by dilution of a short-term infusion of indocyanine green dye and hind-leg oxygen uptake (leg $\dot{V}_{\mathrm{O}_{2}}$ ) by application of the Fick principle, after measuring the arteriovenous difference across the leg (A-EIV) of blood oxygen saturation, and haemoglobin concentration by spectrophotometric methods. Details of these methods have been described previously (Bell, Thompson \& Findlay, 1974).

The measurement of leg $Q$ involves simultaneous sampling of carotid arterial and external iliac venous blood. Portions of whole blood from these samples were taken for analysis of glucose, lactate and pyruvate, and plasma was separated from the remainder by centrifugation at $5^{\circ}$ for estimation of free amino acids and urea, as well as indocyanine green dye concentration. Whole blood was stored in capped syringes in iced water for up to $2 \mathrm{~h}$ before analysis, and plasma was stored at $-20^{\circ}$ for about I month before amino acid analysis. Blood glucose, lactate and pyruvate and plasma urea were measured enzymically with Biochemica Test Combination kits (Boehringer Ltd, London). These methods involved the use of hexokinase (EC 2.7.1.1) and glucose-6-phosphate dehydrogenase (EC I.I.I.49) for glucose estimation, lactate dehydrogenase ( $E C$ I.I.I.27) for lactate and pyruvate, and urease $\left(E C_{3} \cdot 5 \cdot\right.$ I.5) for urea. Individual plasma amino acids were estimated as follows.

Plasma samples were treated with an equal volume of an aqueous solution $(6 \circ \mathrm{g} / \mathrm{l})$ of sulphosalicylic acid added dropwise and with continuous agitation of the mixture. The resulting precipitate was sedimented by centrifugation and a portion of the supernatant solution applied to an automatic amino acid analyser (JEOL (UK) Ltd, London). The analysis was performed following the procedure of Spackman, Stein \& Moore (1958). Using this procedure it was found impossible to distinguish satisfactorily between lysine and ornithine, threonine and glutamine, and serine and asparágine. Therefore results for these amino acids have been expressed as the unseparated fractions lysineornithine, threonine-glutamine and serine-asparagine. The remaining amino acids were assumed to be free from contamination by other ninhydrin-positive substances.

Net exchange across the leg of the metabolites measured in whole blood and their fractional uptake by the leg were calculated from measured values as follows:

$$
\begin{aligned}
\text { net exchange } & =\operatorname{leg} \dot{Q} \times(\mathrm{A}-\mathrm{EIV}) \text { concentration, } \\
\text { fractional uptake } & =\frac{(\mathrm{A}-\mathrm{EIV}) \text { concentration }}{\text { Arterial concentration }} .
\end{aligned}
$$


To calculate the exchange of metabolites measured in plasma, the packed cell volume (PCV) of all arterial samples was estimated by the conventional microhaematocrit technique and leg plasma $\dot{Q}$ was calculated as follows:

$$
\text { leg plasma } \dot{Q}=\operatorname{leg} \dot{Q} \times \frac{100-\mathrm{PCV}}{100} \text {. }
$$

\section{Statistics}

When pairs of results from the two series of measurements made in each experiment were compared, the means of the first and second sets did not differ significantly. Means of the duplicate sets of results were, therefore, used as individual values in all subsequent calculations. The standard error of each treatment mean was estimated, and the significance of the effects of environment and feeding and of any interaction between them was tested using the estimated standard errors of these effects.

\section{RESULTS}

\section{Effects of cold}

As shown in Table I, the cold stress was sufficient to increase total $\dot{V}_{\mathrm{O}_{2}}$ in both feeding groups to a level about twice that of the resting $20 \mathrm{~h}$-fed steer $(P<0.001)$. This was accompanied by 3 - to 5 -fold increases in leg $\dot{Q}(P<0.001)$ and 4 - to 13 -fold increases in leg $\dot{V}_{\mathrm{O}_{\mathrm{g}}}(P<0.00 \mathrm{I})$, while RQ decreased $(P<0.00 \mathrm{I})$ and $\mathrm{PCV}$ increased $(P<0.05)$ in both $20 \mathrm{~h}$ - and $3 \mathrm{~h}$-fed animals.

The results obtained for arterial blood levels and fractional and net leg uptake of glucose, lactate and pyruvate are shown in Table 2 . During cold exposure there was a small but consistent increase $(P<0.01)$ in arterial glucose concentration in both feeding groups. Fractional uptake of glucose by the leg increased $(P<0.05)$ in the $20 \mathrm{~h}$-fed group only, as shown by the significant interaction between environment and feeding effects (Table 2). This meant that in the $20 \mathrm{~h}$-fed animals there was a very great increase ( $\mathrm{I} 7$-fold) in net glucose uptake in the cold which was due both to increased extraction of arterial glucose, and to increased leg $\dot{Q}$. In the $3 \mathrm{~h}$-fed group there was a lesser increase $\left(3^{\cdot} 5^{-}\right.$-fold), reflecting the increase in leg $Q$ only.

Cold had no significant effect on blood lactate levels. However, the significant $(P<0.05)$ interaction between environment and feeding effects on fractional uptake was the result of cold causing a substantial change from a negative to a positive arteriovenous $(\mathrm{A}-\mathrm{V})$ difference across the leg in the fed group only. Thus there was a significant $(P<0.05)$ increase in net leg output of lactate in the cold-exposed, $20 \mathrm{~h}$-fed steers, but an even greater change in the opposite direction in the $3 \mathrm{~h}$-fed group.

Cold had no significant effects on pyruvate levels, or on fractional or net exchange by the leg, although the net output from the leg, which occurred at all times during all treatments, increased during cold exposure.

Since cold had no significant effects on the plasma concentrations or net leg exchanges of any individual amino acids or urea, significance of the effect of cold has been omitted from Table 3 . However, when the $t$ test was applied to mean total amino acid levels, a significant $(P<0.01)$ decrease during cold exposure was demonstrated in the 
Table I. Effects of cold and feeding on total oxygen consumption (total $\dot{\mathrm{V}}_{\mathrm{O}_{2}}$ ), respiratory quotient $(\mathrm{RQ})$, arterial packed cell volume (PCV), leg blood flow (leg $\dot{\mathrm{Q}})$ and leg oxygen uptake $\left(\right.$ leg $\left.\dot{\mathrm{V}}_{\mathrm{O}_{2}}\right)$ in steers

(Mean values with their standard errors for three animals/treatment)

\begin{tabular}{|c|c|c|c|c|c|c|c|c|c|c|}
\hline \multirow[b]{2}{*}{ Treatment } & \multicolumn{2}{|c|}{$\begin{array}{c}\text { Total } \dot{V}_{\mathrm{O}_{2}} \\
(\mathrm{ml} / \mathrm{kg} \text { per } \mathrm{min})\end{array}$} & \multicolumn{2}{|c|}{$\mathbf{R Q}$} & \multicolumn{2}{|c|}{ PCV } & \multicolumn{2}{|c|}{$\begin{array}{c}\text { Leg } \underset{(\mathrm{ml} / \mathrm{min})}{Q} \\
.\end{array}$} & \multicolumn{2}{|c|}{$\underset{(\mathrm{ml} / \mathrm{min})}{\operatorname{Leg} \dot{V}_{\mathrm{o}_{2}}}$} \\
\hline & Mean & SE & Mean & $\mathrm{SE}$ & Mean & $\mathrm{SE}$ & Mean & SE & Mean & $\mathrm{SE}$ \\
\hline $\begin{array}{c}\text { Thermoneutral } \\
\text { 2o h-fed } \\
3 \mathrm{~h} \text {-fed }\end{array}$ & $\begin{array}{l} \\
4 \cdot 36 \\
5 \cdot 76\end{array}$ & $\begin{array}{l}0.27 \\
0.51\end{array}$ & $\begin{array}{l}0.93 \\
I \cdot 08\end{array}$ & $\begin{array}{l}0.02 \\
0.00\end{array}$ & $\begin{array}{l}0.28 I \\
0.279\end{array}$ & $\begin{array}{l}0.014 \\
0.012\end{array}$ & $\begin{array}{l}365 \\
560\end{array}$ & $\begin{array}{l}18 \\
42\end{array}$ & $\begin{array}{r}9 \cdot 93 \\
19.14\end{array}$ & $\begin{array}{l}I \cdot 15 \\
3 \cdot 26\end{array}$ \\
\hline $\begin{array}{l}\text { Cold } \\
20 \mathrm{~h} \text {-fed } \\
3 \mathrm{~h} \text {-fed }\end{array}$ & $\begin{array}{l}9 \cdot 72 \\
9 \cdot 35\end{array}$ & $\begin{array}{l}0.42 \\
I .01\end{array}$ & $\begin{array}{l}0.87 \\
0.97\end{array}$ & $\begin{array}{l}0.00 \\
0.01\end{array}$ & $\begin{array}{l}0.313 \\
0.302\end{array}$ & $\begin{array}{l}0.009 \\
0.005\end{array}$ & $\begin{array}{l}\text { I } 894 \\
1715\end{array}$ & $\begin{array}{l}300 \\
227\end{array}$ & $\begin{array}{r}129 \cdot 6 \\
86 \cdot 9\end{array}$ & $\begin{array}{l}26 \cdot 1 \\
11 \cdot 3\end{array}$ \\
\hline $\begin{array}{l}\text { Significance of } \\
\text { Environ- } \\
\text { ment }(E)\end{array}$ & \multicolumn{2}{|c|}{ *** } & \multicolumn{2}{|c|}{$* * *$} & \multicolumn{2}{|c|}{ * } & \multicolumn{2}{|c|}{$* * *$} & \multicolumn{2}{|c|}{ **** } \\
\hline $\begin{array}{l}\text { Feeding }(F) \\
E \times F\end{array}$ & & & & & & & & & \multicolumn{2}{|c|}{ NS } \\
\hline
\end{tabular}

NS, not significant. * $P<0.05, * * * P<0.001$.

$20 \mathrm{~h}$-fed groups only. The lack of a significant cold-induced change in individual or total amino acid net exchange across the leg indicates that $\mathrm{A}-\mathrm{V}$ differences were decreasing as leg $\dot{Q}$ increased.

\section{Effects of feeding}

Although recent feeding tended to increase total $\dot{V}_{\mathrm{O}_{2}}$, RQ, leg $\dot{Q}$ and leg $\dot{V}_{\mathrm{O}_{2}}$ during thermoneutrality, this effect was significant in both environments for RQ only $(P<0.001)$. Comparison of thermoneutral values only showed that leg $\dot{Q}$ increased significantly $(P<0.05)$ after feeding.

Feeding did not affect the arterial level of glucose but leg glucose uptake increased significantly $(P<0.05)$ in the thermoneutral environment only. Arterial lactate levels tended to be higher after feeding, but this trend was variable and not statistically significant (Table 2). Leg output of lactate was greater in the recently-fed steers during thermoneutrality, but during cold exposure the fed group consistently took up significant amounts of lactate while their fasted counterparts showed an increased leg output (Table 2). Pyruvate levels increased after feeding in thermoneutrality $(P<0.05)$ but not cold; this interaction was significant $(P<0.05)$. Feeding did not affect exchange of pyruvate across the leg.

As shown in Table 3 , recent feeding caused increases in arterial plasma levels of most individual amino acids, these being significant for arginine, threonine-glutamine, tyrosine and phenylalanine $(P<0.05)$ and alanine and methionine $(P<0.01)$. Net exchanges of individual amino acids across the leg were variable, and, with the exception of arginine and glutamate, feeding caused no significant changes according to the over-all statistical analysis. However, much of the variation occurred in the coldexposed groups and comparison of the thermoneutral groups only, gave a somewhat 


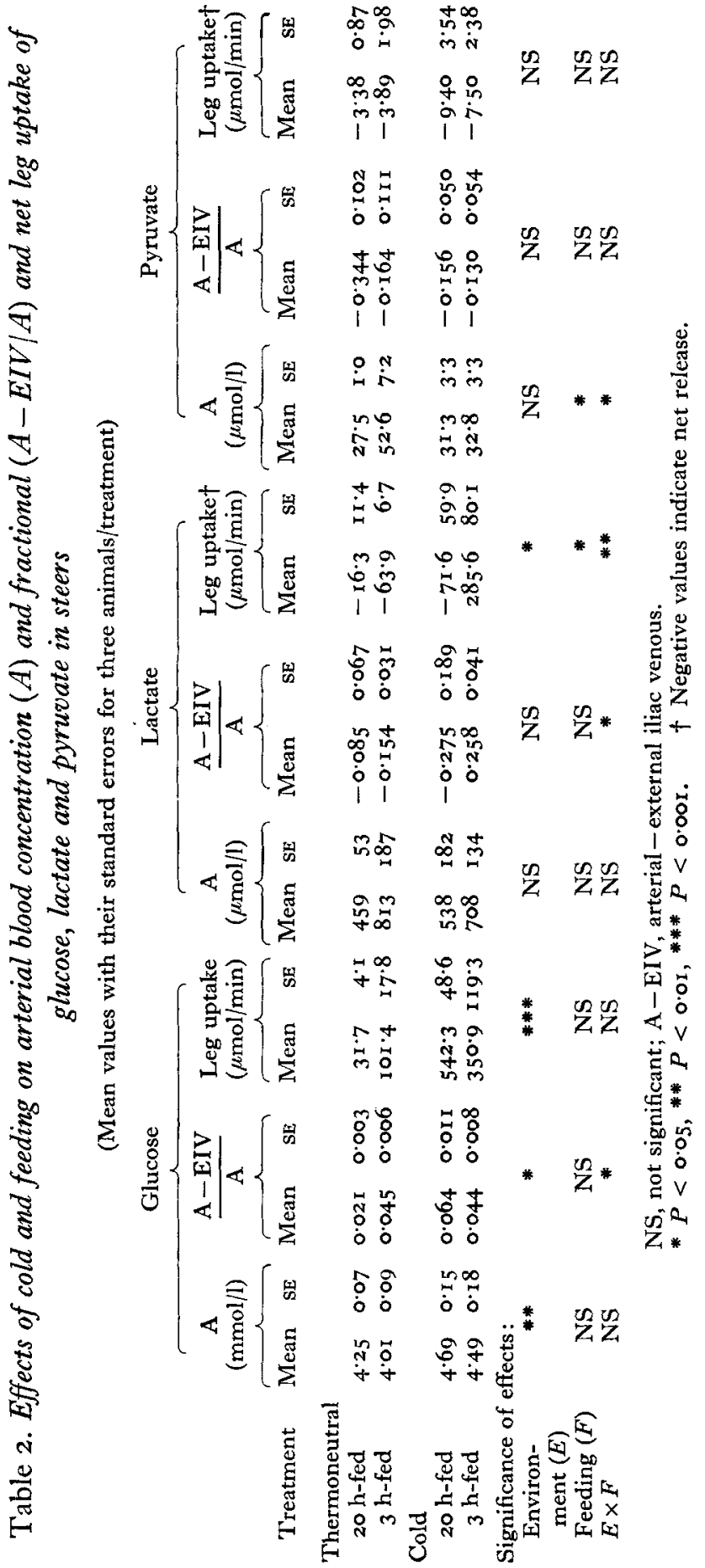




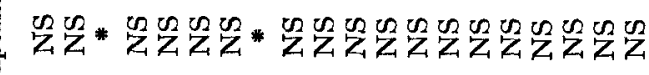

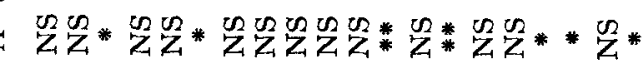

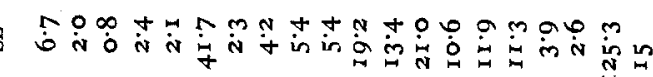
"艹

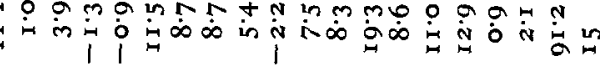

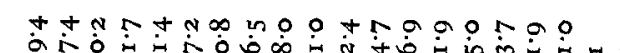

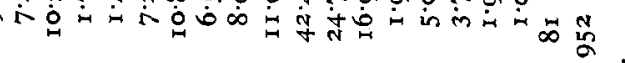

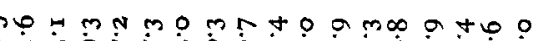

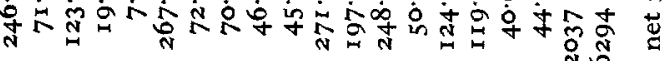

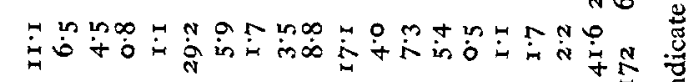

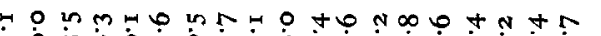
$+3$ i

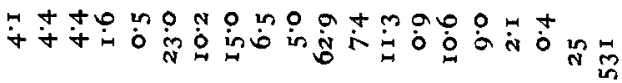

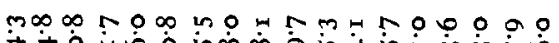
士

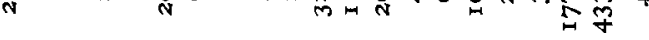

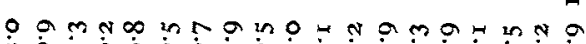
तं o on - 1 in 1 in

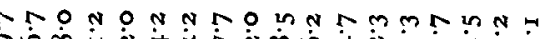
位 N

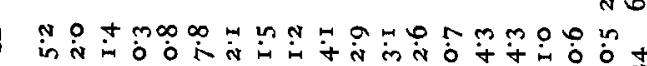

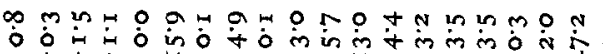
o 1 i

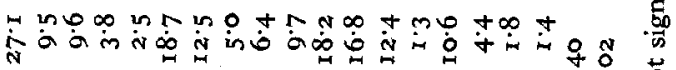

m mo o no $n$ n

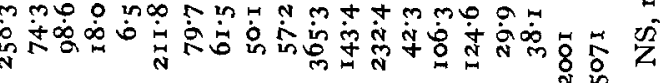

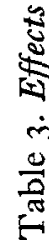

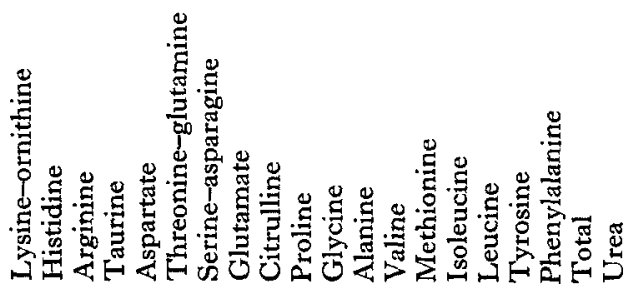


different picture. In the $20 \mathrm{~h}$-fed steers there was a mean net output of most amino acids, which was greatest for threonine-glutamine and alanine, and this was reflected by the total amino acid net output (Table 3 ). This was reversed to a similar net uptake following feeding, and this change was significant for lysine-ornithine, histidine serine-asparagine, glutamate, valine and phenylalanine $(P<0.05)$ and alanine $(P<0.0 \mathrm{I})$.

Feeding caused a significant increase $(P<0.05)$ in the arterial plasma urea concentration, but had no effect on net exchange of urea across the leg.

\section{DISCUSSION}

The arterial blood glucose levels of the young steers used in this study were consistently higher than that considered normal ( $3 \mathrm{mmol} / \mathrm{l})$ for non-pregnant, non-lactating adult cattle. Several factors may account for this. First, there is some evidence that bovine blood glucose concentration has not completely decreased to adult levels even by 6 months of age (Kennedy, Anderson, Bechdel \& Shigley, 1939; McCandless \& Dye, I950; Davis \& Brown, 1962), although only the latter study used an enzymic technique specific for glucose. Secondly, after completion of the present experiments it was discovered that the stress of pre-experimental handling, including cannulation of the exteriorized carotid artery, caused a small delayed increase in blood glucose level which was still apparent at the time when experiments normally began. However, values derived from samples obtained by venepuncture in the animal byre before cannulation were still similar to those obtained during experiments at thermoneutrality. Thirdly, there may have been a dietary effect on blood glucose, since the animals were fed a ration containing $220 \mathrm{~g}$ molasses and $\mathrm{I} 70 \mathrm{~g}$ rolled barley/kg and it has been shown in sheep that glucose entry rates increase with increasing digestible energy intake (Leng, 1970). Also, during the course of the study glucose was estimated in plasma, as well as whole blood, in samples from several animals. Using these values and PCV measurements it was calculated that the erythrocyte fraction of most samples contained appreciable amounts of glucose (up to $\mathrm{I} \cdot 7 \mathrm{mmol} / \mathrm{l}$ ). Thus, plasma glucose values were more similar to commonly reported plasma glucose levels than the whole blood values might indicate. This apparent permeability of erythrocytes to glucose contrasts with the very low glycolytic activity of adult sheep erythrocytes (Leng 8 Annison, I962) but conforms with the early literature on the distribution of blood sugar in bovine blood (Andreen-Svedberg, 1933; Somogyi, 1933), which is rather surprising considering the non-specific nature of the analyses then available.

The literature contains very little information on the effect of cold exposure on carbohydrate metabolism in ruminants, and equally little is known about carbohydrate utilization by shivering (as opposed to exercising) skeletal muscle in any species. However, the increased blood glucose concentrations due to cold in the present study agree with similar observations on sheep last fed $12 \mathrm{~h}$ before an acute cold exposure sufficient to double metabolic rate (McKay et al. I974), and on non-pregnant, nonlactating cows exposed to sub-zero temperatures for several days (Olsen \& Trenkle, I973). It is likely that the initial increase, at least, stemmed from hepatic glycogenolysis 
Table 4. Effects of cold and feeding on net glucose equivalent (net CHO) uptake by the hind leg of steers and its possible contribution to oxidative metabolism

(Mean values for three animals/treatment)

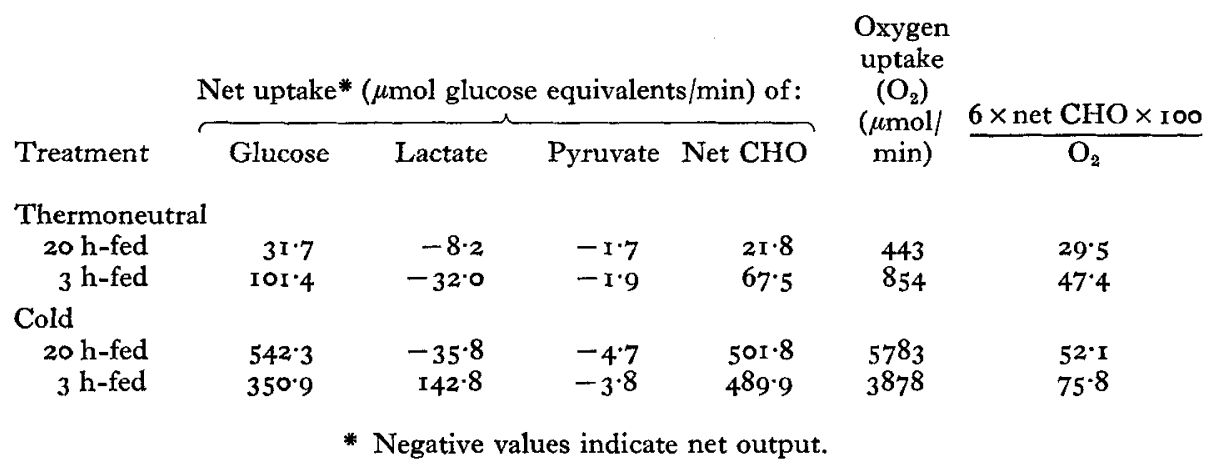

due to direct sympathetic nervous stimulation, as demonstrated in the young calf (Edwards \& Silver, 1970). Cold exposure has been shown to increase sympathetic nervous activity in adult steers (Thompson \& Clough, 1972). Liver glycogen reserves were then possibly conserved by enhanced rates of gluconeogenesis, since there is evidence that cold exposure causes increased hepatic uptake of glycerol (Thompson, Gardner \& Bell, 1974) and possibly other gluconeogenic substrates in sheep. Cold exposure causes increased plasma glycerol levels in cattle (Bell \& 'Thompson, 1974) as well as sheep (Thompson et al. 1974), almost certainly as a result of increased rates of lipolysis of adipose tissue triglycerides.

The very large increase in glucose uptake by the shivering leg suggests an unexpectedly important role for glucose as a fuel for respiration of muscle during cold exposure. This is perhaps analogous to the increased importance of glucose as a substrate for muscle oxidation during leg exercise in man (Wahren et al. 1971). When mean values for glucose uptake are corrected for lactate and pyruvate output by the leg and compared with oxygen uptake (Table 4 ) it is evident that the potential contribution of glucose to oxidative metabolism of the leg increases about $50 \%$ during cold exposure, whether or not the animal has been recently fed. The estimations for thermoneutrality are much higher than the reported values of less than $20 \%$ for the contribution of glucose to respiratory $\mathrm{CO}_{2}$ in the resting whole animal (Lindsay, 1970; Bergman, 1973). However, the net exchange by the leg of amino acids, many of which can be formed from the carbon skeleton of glucose, was not taken into account. If complete transfer of $\mathrm{C}$ from glucose to amino acids is assumed, it can be calculated that amino acid output in the $20 \mathrm{~h}$-fed steers would largely account for net corrected glucose uptake by the leg during thermoneutrality, although not in the cold. This is not so for the $3 \mathrm{~h}$-fed animals, however, since there was a net leg uptake of amino acids in both environments. McKay et al. (I974) have shown that acute cold exposure of sheep results in a 4 - to 5 -fold increase in the whole-animal oxidation rate of glucose, and that this is associated with an approximate doubling of the contribution of glucose 
to respiratory $\mathrm{CO}_{2}$. They also showed that there is a substantial increase in the proportion of glucose turnover oxidized during cold exposure. The high rates of leg glucose uptake in the present experiments may be partly explained by increased glucose availability, due to factors discussed earlier. There is evidence that in both sheep (Annison \& White, I96I) and cattle (Bartley \& Black, I966) exogenous administration of glucose causes increased glucose oxidation. It is also notable that values for leg uptake of glucose obtained in the present study do not appear excessive when compared with values for whole-animal glucose turnover rate in cattle of similar age and body-weight (Davis \& Brown, 1962).

Cold exposure produced a marked increase in the $\mathrm{A}-\mathrm{V}$ difference in glucose across the leg in the $20 \mathrm{~h}$-fed, but not in the $3 \mathrm{~h}$-fed steers, and there was also a substantial cold-induced uptake of lactate in the $3 \mathrm{~h}$-fed group, but not in the $20 \mathrm{~h}$-fed group. The reason for the former observation is not clear, particularly since it is likely that insulin levels were low due to both short-term fasting (Trenkle, 1970) and cold exposure (Bassett \& Alexander, 1971). Cold exposure has been shown to increase rates of production and utilization of lactate without changing its plasma concentration in dogs (Minaire, Pernod, Jomain \& Mottaz, 1971). It thus appears that when it is present in sufficient quantities and metabolic demand is great enough, blood lactate can become a significant fuel for muscle metabolism.

These experiments have provided no evidence for an increased contribution to hepatic gluconeogenesis from amino acids released from leg muscle during cold exposure. This was not entirely unexpected, since although ruminants depend to a large extent on gluconeogenesis for their glucose supply (Bergman, 1973), our young growing steers were in positive net nitrogen balance and even after $20 \mathrm{~h}$ without food would have had a significant supply of amino acids from the gut. This contrasts with the exercising, postabsorptive human subjects for which Felig \& Wahren (1971) reported an acceleration of the so-called 'glucose-alanine cycle'. The decrease in total amino acid level during cold exposure of the $20 \mathrm{~h}$-fed animals was not due to decreased output from the leg, or presumably, other muscle. It remains possible that amino acid absorption from the gut was somehow affected. Recent evidence suggests that erythrocytes, as well as plasma, are involved in the transport of amino acids to and from human tissues, including leg muscle (Felig, Wahren \& Räf, 1973). However, since this work also showed that exchanges occurring in plasma largely parallel those in whole blood, it is unlikely that estimation of whole blood amino acids in the present study would have led to different conclusions.

To the authors' knowledge these results are the first reported for individual amino acid uptake by the hind leg, which is predominantly skeletal muscle, in ruminants. Table 3 shows the effect of recent feeding on leg uptake of amino acids, and although not an important aim in the present experiments, this approach may prove useful in the study of amino acid utilization and muscle growth in young ruminants.

The surgical assistance of Mrs J. N. Hunter and the technical assistance of Mrs J. M. N. Hunter, Misses J. Veitch and E. Waugh and Mr P. Kirby is gratefully acknowledged. 


\section{REFERENCES}

Andreen-Svedberg, A. (1933). Skand. Arch. Physiol. 66, I I3.

Annison, E. F. \& White, R. R. (I96I). Biochem. F. 80, 162.

Bartley, J. C. \& Black, A. L. (1966). F. Nutr. 89, 317.

Bassett, J. M. \& Alexander, G. (I971). Biologia Neonat. I7, I 12.

Bell, A. W., Gardner, J. W. \& Thompson, G. E. (1974). Br. F. Nutr. 32, 47 r.

Bell, A. W. \& Thompson, G. E. (1974). Res. vet. Sci. 17, 265.

Bell, A. W., Thompson, G. E. \& Findlay, J. D. (1974). Pfiügers Arch. ges. Physiol. 346, $34 \mathrm{I}$.

Bergman, E. N. (1973). Cornell Vet. 63, 341.

Black, A. L., Egan, A. R., Anand, R. S. \& Chapman, T. E. (1968). Isotope Studies on the Nitrogen Chain p. 247. Vienna: International Atomic Energy Agency.

Davis, C. L. \& Brown, R. E. (1962). F. Dairy Sci. 45, 513.

Edwards, A. V. \& Silver, M. (r970). F. Physiol., Lond. 21r, rog.

Felig, P. \& Wahren, J. (1971). F. clin. Invest. 50, 2703.

Felig, P., Wahren, J. \& Räf, L. (1973). Proc. natn. Acad. Sci. U.S.A. 70, 1775.

Kennedy, W. L., Anderson, A. K., Bechdel, S. I. \& Shigley, J. F. (1939). F. Dairy Sci. 22, 25 I.

Leng, R. A. (1970). Adv. vet. Sci. r4, 209.

Leng, R. A. \& Annison, E. F. (1962). Aust. F. agric. Res. 13, 3r.

Lindsay, D. B. (1 970). In Physiology of Digestion and Metabolism in the Ruminant p. 348 [A. T. Phillipson, editor]. Newcastle upon Tyne: Oriel Press.

McCandless, E. L. \& Dye, J. A. (r950). Am. F. Physiol. 162, 434.

McKay, D. G., Young, B. A. \& Milligan, L. P. (I974). In Energy Metabolism of Farm Animals p. 39 [K. H. Menke, H.-J. Lantzsch and J. R. Reichl, editors]. Hohenheim: Universität Hohenheim Dokumentationsstelle.

McLean, J. A. \& Calvert, D. T. (1972). F. agric. Sci., Camb. 78, 303.

Minaire, Y., Pernod, A., Jomain, M.-J. \& Mottaz, M. (197I). Can. F. Physiol. Pharmac. 49, 1063.

Olsen, J. D. \& Trenkle, A. (1973). Am. F. vet Res. 34, 747.

Reilly, P. E. B. \& Ford, E. J. H. (I 97I). Br. F. Nutr. 26, 249.

Somogyi, M. (1933). f. biol. Chem. 103, 665.

Spackman, D. H., Stein, W. H. \& Moore, S. (1958). Analyt. Chem. 30, I I9o.

Thompson, G. E. \& Clough, D. P. (1972). Q. Yl exp. Physiol. 57, 192.

Thompson, G. E., Gardner, J. W. \& Bell, A. W. (1974). Int. Un. Physiol. Sci. XXVI int. Congr. Abstr. Vol. 11, p. 407 .

Trenkle, A. (г970). F. Nutr. roo, r323.

Wahren, J., Felig, P., Ahlborg, G. \& Jorfeldt, L. (I971). F. clin. Invest. 50, 2715.

Wolff, J. E. \& Bergman, E. N. (1972). Am. F. Physiol. 223, 455. 